\title{
LANDLORD'S TORT LIABILITY FOR DISREPAIR
}

\section{LAURENCE H. EldREDGe $†$}

This article concerns itself with the liability of a landlord who has not covenanted to make repairs for injuries caused by a condition existing on the leased premises at the time he gives possession under the lease. The recent decision of the Supreme Court of Pennsylvania, by a divided court, in the case of Deutsch $v$. Max, ${ }^{1}$ enormously extends a landlord's liability for injuries to persons who come upon the land, and the opinion of the majority of the court finds no support in the authorities it cites, nor in any other decision of a court of last resort. The case is so clearly contrary to the settled American and English law as to merit a re-examination of this whole question, in order to determine the proper basis for imposing liability upon a landlord and to ascertain whether, regardless of precedent, presentday conditions are such as to make such a change in the law socially desirable. Changes in social conditions frequently require changes in legal rules to meet them. ${ }^{2}$ The dead hand of the past should not be a bar to a rule of law which may be necessary to society as it exists in the year 1935, but unless the need for such a change is clear, a unanimity of American and English authority should not lightly be discarded.

The principles which determine the duties of owners and other possessors of land to persons coming upon the land and to persons outside the land, with respect to conditions existing or activities carried on upon the land, are a part of the vast and ever growing law of negligence. These particular principles are, however, colored by a persistence of certain theories of immunities of landowners which grew up in the days of feudal England. The developing conception of the law of negligence has tended more and more to restrict the early privileges of possessors of land, but there is still a marked persistence in many jurisdictions of rules of law which exculpate possessors of land from liability, particularly with respect to trespassers who are in fact, if not in legal theory, quite likely to go upon the land. It is a curious fact that the Supreme Court of Pennsylvania, which has been traditionally conservative with respect to the duties of landowners in possession to persons coming upon the premises, should in Deutsch v. Max so sweepingly extend the duties of a landowner out of possession.

The principles which determine the extent of a landlord's tort liability for injuries caused by conditions upon the land are a part of the law which

†B.S., 1924, Lafayette College; LL. B., I927, University of Pennsylvania; Adviser, Restatement, ToRTs (1934) ; member of the Philadelphia County, Pennsylvania, Bar.

I. $318 \mathrm{~Pa} .450$, I78 Atl. $48 \mathrm{I}$ (1935).

2. A notable example is MacPherson v. Buick Motor Co., 217 N. Y. 382, III N. E. I050 (IgI6), and the cases following it. 
determines the duties of owners and possessors of land generally. In approaching the problems which arise, it is important to keep in mind the distinction between misfeasance and nonfeasance. The normal conception of negligence is the doing of an act in a manner which creates an unreasonable danger of invading the legally protected interests of another person or group of persons. It is only in the exceptional situation that the failure to act subjects one to liability. ${ }^{3}$

With respect to owners and other possessors of land, it is also fundamental to distinguish between the duties which are owed to persons coming upon the land, on the one hand, and to persons outside the land, on the other. Normally, a person in legal possession of land is privileged to exclude therefrom any and all persons. Aside from situations involving certain specific law-given privileges to go upon the land regardless of the possessor's consent, members of the public do not have any general legal privilege to go thereon. Such privilege must be derived from the consent of the one in possession. The giving of such consent creates a license to enter upon the land. ${ }^{4}$ As this license is a gift which the possessor may grant or withhold, as he sees fit, a gift which the recipient has no legal right to demand, it matters nought whether the gift is of great or little value, or indeed of any value. If $A$ hands to $B$ a package as a gift, $B$ has no right to complain that the package contains worthless rubbish instead of the excellent cigars which he believed were therein. By the same token, one who is given permission to enter upon land in the possession of another has no reason to complain that it is an unsightly dump rather than a beautiful estate. The adage about the inadvisability of looking a gift horse in the mouth is equally applicable to both situations.

On the other hand, the recipient of the package would justly have cause to complain if upon opening it he found therein a rattlesnake, which promptly greeted its new master by sinking its fangs into his hand. ${ }^{5}$ So, too, the recipient of a license to enter upon land may justly complain if while walking thereon the ground gives way beneath him and he finds himself precipitated into a hole which the possessor of the land had prepared to catch some animal. ${ }^{6}$ In both of these situations the donor, in the one case of the package and in the other of the license to enter the land, has not merely presented to the other a gift of no value, but he has actively done something which foreseeably created a serious danger to the recipient of the gift. This is more than a mere nonfeasance. It is a species of fraud. ${ }^{7}$ It is active conduct which leads the innocent and unsuspecting person into a danger

3. Bohlen, Studies in the Law of Torts (1926) 33, 38-65.

4. RestateMrent, ToRTs (I934) § I67.

5. Id. $\$ \S 388,405$.

6. Id. $\$ 342$. (1858).

7. Langridge v. Levy, 2 M. \& W. 519 (Ex. I837) ; Corby v. Hill, 4 C. B. N. S. 556 
which he would not otherwise encounter. However, it is submitted that if the intending donor of the rattlesnake advised the intended donee in advance of the contents of the package, and the latter, with knowledge of the facts, accepted the gift, the donor would be under no liability for any untoward consequences which might thereafter result to the donee. ${ }^{8}$ The situation would be one of a true voluntary assumption of risk, as distinct from that particular type of contributory negligence which is so frequently called by courts "assumption of risk." The term "contributory negligence" implies that the defendant himself has violated a duty owed to the plaintiff. In the hypothetical case just cited, the full extent of the donor's duty is to acquaint the donee with the nature of the gift, in order to enable the donee to exercise an intelligent choice about accepting a gift of such dubious value. If this be done, there can be no question of negligence as to the defendant, nor can there be any question of contributory negligence. The plaintiff voluntarily, and of his own choice, assumes the risk of being bitten.

Likewise, the extent of the duty of the possessor of land to the donee of a license to enter thereon is merely to take reasonable care to apprise the prospective donee of the license to enter of those hidden dangers on the land which are known to the possessor, in order that the donee may exercise an intelligent choice as to whether he desires to accept a gift whose value may be as dubious as that of the rattlesnake. ${ }^{9}$ If, with knowledge of the existence of the cleverly concealed hole in the ground, the donee nonetheless accepts the gift of the license to enter, he voluntarily assumes the risk of falling therein. Again, it is not a question of contributory negligence, because there is no antecedent breach of duty by the possessor of the land. His duty was fulfilled by the warning which he gave. In the absence of a warning, the possessor would be subject to liability for having actively led the other into a trap. The only reason for requiring the warning to be given is to enable the other to exercise an intelligent choice. It follows that where the other himself has knowledge of the danger, there is no duty to warn. Obviously, in the illustration already given, if the package containing the rattlesnake were in the form of a glass case through which the snake was clearly visible, and the intended donee of the snake was thoroughly familiar with snakes in general, and rattlesnakes in particular, the failure of the donor in the course of handing the package to the donee to say, "This is a rattlesnake", could not become the basis of imposing any liability for injuries thereafter caused to the donee by the snake. ${ }^{10}$ So too, the failure of the possessor of land to call to the attention of the donee of the license to enter dangerous conditions existing upon the land which are known to both

8. See Restatemient, Torts (1934) $\$ 388$, comment $i$.

9. Id. $\$ 342$, comment $c$.

Io. $I d$. $\S 388$, comment $i$. 
parties or which are so obvious that the possessor reasonably believes they will be observed by the other when entering upon the land, cannot form the basis of liability for injuries to the other received from such conditions. ${ }^{11}$

The foregoing applies to all true licensees entering upon land, regardless of whether they enter for purposes of their own and are therefore, in legal phraseology, "licensees", or whether they enter in connection with something as to which the possessor of the land has a business interest, and are therefore "invitees." The only difference in the duties owed by a possessor of land to a licensee and to an invitee is that as to the former, the possessor is only required to give warning to the licensee of danger which, to the knowledge of the possessor, exists upon the land and which he reasonably believes will not be observed by the licensee; while, as to the latter, he is required to make inspections in order to discover hidden existing dangers, concerning which he must then give warning. ${ }^{12}$ This additional duty to take active steps to discover unknown defects in order to warn the invitee against them, is the price which the law imposes upon the possessor for the benefit which he derives from the invitee's presence. ${ }^{13}$

In the average case, insofar as business establishments are concerned, when dangerous conditions are known or are discovered to exist, they are promptly remedied, because otherwise people who were warned of their existence would be discouraged from entering and trading. It is seldom that the question arises where a warning has been given. The courts do not generally talk of the duty as one to warn the invitee of what conditions he will find upon entrance. They generally speak of a duty to invitees to make safe dangerous conditions which are known or which a reasonable inspection would disclose. These expressions of opinion must always be considered in the light of the facts of the cases in which they are uttered. Such facts nearly always disclose situations where the invitee had no knowledge of the dangerous condition and no steps had been taken by the possessor to apprise him of it.

But there can be no doubt that the possessor of the land can satisfy his duty to even that most highly favored type of invitee, the cash customer in a merchandising store, by either keeping the store in a safe condition or by bringing home to the customer the fact that dangers do exist. For example, a wealthy and eccentric collector of fine jewels maintains a shop in a business district, in which he buys and sells jewels of the first water. The floor of the shop has fallen into such an obvious state of disrepair as to endanger any one who walks upon it. In addition, an overhead chandelier has become so loosened as to constitute a constant peril to one beneath it. A customer

II. $I d . \S 342$, comments $b$ and $c$.

I2. $I d$. $\S 343$, comment $a$.

13. BoHLEN, op. cit. supra note 3, at 45-65. 
entering the shop not only sees these conditions but reads a sign by the door which clearly recites the above facts. Nonetheless, in his desire to purchase a particularly fine jewel, he persists in entering, whereupon the chandelier falls upon him, fracturing his skull, and the floor gives way, breaking his leg. Under settled legal principles, the owner of the shop is subject to no liability. ${ }^{14}$ The customer had no legal right to invade the shop even for a business purpose, and the possessor of the shop discharged his full duty when he gave adequate warning of the conditions to be met if the customer accepted the gift of the license to enter. It should be made clear that the customer's failure to recover is not based upon the affirmative defense of contributory negligence, but upon the lack of any breach of duty by the shop keeper. This is important, because where there is no breach of duty, the defendant is entitled to a nonsuit, whereas in the defense of contributory negligence, if reasonable men may differ in their conclusions concerning the issue of contributory negligence, the question is one for the jury, even upon undisputed facts.

The true basis of the rule which imposes liability upon a possessor of land for conditions thereon is emphasized by the difference in the duty which is imposed in those exceptional cases where the one going upon the land for a purpose connected with business dealings with the possessor does not derive his privilege to enter from the consent of the possessor but has a lawgiven privilege to enter. In such a case, the person entering the land is not accepting a gift from the possessor, and if the possessor has a business interest in the visit, he does not fulfill his duty unless he exercises reasonable care to make safe such conditions as are known to be dangerous or whose danger is discoverable by a reasonable inspection. ${ }^{15}$ The same distinction is the basis of the difference between the duty which a possessor of land owes to persons coming upon the land pursuant to a privilege created by the possessor's consent and the duty which a possessor of land owes to people who are outside the land, such as persons upon adjacent land or upon contiguous public highways. Such persons in no way derive from the possessor of the land in question their legal right to be upon adjacent land as owners thereof or otherwise, nor do they derive from the possessor of the particular land their right as members of the public to use the highway in the exercise of the privilege of travel thereon. ${ }^{16}$ Consequently, the law is definitely established that the possessor of land has a greater duty than a mere duty to give warning of dangerous conditions existing upon his own premises which create an unreasonable risk of injury to persons outside the

I4. See Mitchell v. George A. Sinn, Inc., 308 Pa. 1, 6, I6I Atl. 538, 539 (I932); RESTATEMENT, ToRTS (I934) § 343 .

I5. RESTATEMENT, TORTS (1934) § 347. An example of this situation is where a patron of a public utility enters upon that portion of land possessed by the utility which it is reasonably necessary for him to go on in order to secure those services of the utility to which he is legally entitled.

I6. Id. \& I92. 
land. As to such persons, the possessor, whether in possession as owner or otherwise, has a duty to such persons to exercise reasonable care to maintain structures and other artificial conditions upon the land in such manner as not to endanger persons outside the land. ${ }^{17}$ Where such dangerous conditions exist, they frequently partake of the nature of a true nuisance. An overhanging cornice which is in such a state of disrepair as to be likely at any minute to drop on passers-by on the highway, is as much a danger to law ful highway travel as is an obstruction in that highway.

The principles which specifically determine the extent of a landlord's duty for dangerous conditions existing upon his land, at least insofar as they relate to dangers existing at the time possession is given under a lease, are merely applications of the foregoing principles which apply to all possessors generally. The landlord is under no more legal duty to lease the land to a tenant and permit him to go thereon, pursuant to the consent embodied in the lease, than he is under a legal duty to permit any other person to go upon the land. Therefore, the tenant has no legal right to demand that the land shall be in any particular condition as respects its safety. Like any other person entering upon the land pursuant to a privilege created by the consent of the possessor, the most the tenant can ask is that the landlord disclose those dangerous conditions which are known to him to exist and which will probably not be discovered by the tenant in the course of such lay inspection as he can reasonably be expected to make. A landlord who gives possession to a tenant of land containing, to the landlord's knowledge, dangerous hidden defects, is guilty of active wrongdoing, because he commits an act which almost inevitably draws the tenant into a hidden trap. ${ }^{18}$

On the other hand, where the tenant is told of existing dangerous conditions by the landlord, or becomes aware of them by the use of his own senses either because they are obvious or because he has made an inspection which discloses them, the legal duty of the landlord is completely discharged, and the tenant must exercise his own judgment as to taking possession of the land. There can be no doubt but that this, as a general rule, represents the settled law in England and America. ${ }^{19}$ It is an equally well settled gen-

I7. Id. $\$ \S 364,365$.

I8. Id. $\$ 358$.

19. Id. $\$ 356$; BоHLEN, op. cit. supra note 3 , at 207-208; I TIFFANY, LANDLORD AND TENANT (I910) 556,649,652; POLLOCK, TORTS (12th ed.) 537; I6 R. C. L. (I917) $\$ \S 555,588$; Notes (IgII) 34 L. R. A. (N. s.) 798; (IgI2) 39 id. 378; L. R. A. 1916D I224; id. I9I6F IO8r, II40. Even where the landlord covenants to repair, the majority rule denies any tort liability. Notes (I920) 8 A. L. R. 765 ; (1930) 68 id. II94. A frequently quoted statement of the English law is that of Chief Justice Erle: "A landlord who lets a house in a dangerous state, is not liable to the tenant's customers or guests for accidents during the term; for, fraud apart, there is no law against letting a tumble-down house. . . Robbins v. Jones, I5 C. B. N. S. 22I, 240 (1863). Chief Justice Holmes said: "As the landlord makes no contract concerning the condition of the premises at the time, the only ground on which he can be held is that he unconscionably is leading the other party into a trap. . . . The duty when it exists is only a duty to inform the tenant of the danger, and 'there can be no such duty without knoweldge of the defect'." O'Malley v. Twenty-Five Associates, I78 Mass. 555, 558, 60 N. E. 387 (I9OI). 
eral rule that the landlord owes no greater duty to third persons coming. upon the land in the right of the tenant (i.e., in the exercise of a privilege to enter created by the tenant's consent to their entry) than that which is owed to the tenant. ${ }^{20}$ When the landlord warns the tenant of existing dangers he has given as much warning as is possible. He cannot stand guard at the entrance of the premises during the term of the lease and repeat the warning to every person who goes upon the land. ${ }^{21}$

It is submitted that the decision of the majority of the Supreme Court of Pennsylvania in Deutsch v. Max, is irreconcilable with the foregoing principles. The defendant owned a three-story frame building, which he leased for a term of three years as a grocery store and dwelling. At the time the tenant took possession, the wooden balustrades of a second-story front porch, fronting on the street, were defective and decayed from age, as was known to both landlord and tenant at the time the latter took possession. The landlord made no covenant or other agreement to make any repairs. Two and a half years later, no repairs having been made, a domestic servant of the tenant, while leaning against the balustrade shaking a carpet, fell when the balustrade gave way, receiving serious permanent injuries. She first brought suit against the landlord and the tenant jointly, and at the trial of that action a nonsuit was entered as to the landlord, and there was a verdict for the plaintiff against the tenant. Finding the tenant to be judgment-proof, a second suit was instituted against the landlord alone, five months after the first verdict. In this action a verdict in favor of the plaintiff was returned for $\$ 7000$, but thereafter the trial court entered judgment for the defendant, upon the ground that the landlord owed no duty to the plaintiff. By a five-to-two decision, the judgment was reversed, and judgment ordered entered on the verdict. A vigorous dissenting opinion was filed by Mr. Justice Drew, in which Mr. Justice Schaffer concurred. In the majority opinion, written by $\mathrm{Mr}$. Justice Maxey, it was said:

"This case is ruled by the principle that where a landlord lets premises in a ruinous condition or in a condition amounting to $a$ misance, the landlord is liable for injuries resulting therefrom. This principle has been recognized in numerous cases in this and other jurisdictions." 22

It is submitted that the principle cited is entirely inapplicable to the facts of the case. In the early common law, a possessor of land was per-

20. See authorities cited supra note 19.

2I. "A different rule, requiring the lessor to give such information to every person whom the lessee may allow upon the premises, would impose on the lessor the duties of an occupant while divested of the benefits, and would in effect prevent the leasing of any premises in which there is a concealed source of danger to persons who might enter thereon." I TIFFANY, op. cit. supra note 19 , at 653 .

22. 3I8 $\mathrm{Pa}$. at $453, \mathrm{I7} 8 \mathrm{Atl}$. at 482 . 
mitted to do pretty much as he chose upon the land both with respect to creating conditions and carrying on activities thereon. However, when a possessor of land conducted himself in such a manner as to invade the legally protected interests of strangers to the land, such as adjacent land owners or travellers upon near-by highways, a clash of legally protected interests resulted, and to meet this situation the maxim sic utere tuo ut alienum non laedas came into the law. That maxim is the underlying basis of the law of nuisance, and it was primarily designed to protect the interests of other landowners in the undisturbed possession and enjoyment of their own land. To a large extent, the maxim is more properly one of property law than of tort law. Consequently, a possessor of land could not be guilty of creating a nuisance thereon unless its effects went beyond his own boundaries. While the term "nuisance" is a vague and somewhat elastic one, the normal conception of nuisance is restricted in this manner, and common examples are cases in which a person creates a condition or carries on an activity upon his own land which causes smoke, or stenches, or vibrations, or water, or other things, to be carried upon adjacent land and interfere with its use and enjoyment. It is wholly alien to the underlying conception of the theory of nuisance and its development in the common law, to refer to a condition or activity which can only be injurious to a person who goes upon the land on which it exists, as a nuisance.

The problem was clearly seen by the court in the leading case of Burdick v. Cheadle. ${ }^{23}$ The defendant was a landlord who had leased a property for a grocery store, and in which there were defective shelving and fixtures. These gave way, injuring the plaintiff, who was lawfully in the store as a customer of the tenant, injuring him. In sustaining a demurrer to the declaration, Justice McIlvaine said:

“. . . the liability of the defendant, Cheadle, existed only in favor of persons standing strictly upon their rights as strangers to the property, and as to whom it was the duty of the defendant to remove or repair the structures. The duty here referred to does not arise upon the contract of lease, but is one which the law imposes upon the owners of property, and is expressed in the maxim, sic utere tuo ut alienum non laedas.' . . . But the plaintiff was not a stranger, standing strictly upon his rights as such. Indeed, the noxious fixtures complained of did not amount to a nuisance at all in the legal sense of the term. They were not erected or maintained in violation of any right of the public, or of any member of the public. They were unsafe, it is true, but did not tend to endanger the person or property of strangers to the premises. They were unsafe to persons and things which might be for the time being in the storeroom; but no person or thing could rightfully be there, except by the permission and upon the request of the lessees." 24 
The same distinction has recently been pointed out by Chief Justice Peaslee of the Supreme Court of New Hampshire:

"Another conclusive answer to the claim advanced is that the doctrine of liability for nuisance upon premises does not apply as between a landlord and his tenant, or those claiming under the tenant. That doctrine depends upon a theory of unreasonable invasion of one's rights in premises by acts done upon or outside thereof. . . . It cannot be relied upon by the tenant or his invitees as a ground for recovery from the landlord because of defects in the leased premises. . . So long as there was no invasion of the premises by the landlord there was no liability for their condition, in the absence of warranty or deceit." 25

The cases cited and relied upon by Mr. Justice Maxey emphasize the distinction which he did not draw. Knauss v. Brua, ${ }^{26}$ Fow v. Roberts, ${ }^{27}$ and Wunder $v$. McLean, ${ }^{28}$ were all cases in which the plaintiffs were adjacent owners; while Kirchner $v$. Smith ${ }^{29}$ and McLaughlin $v$. Kelly ${ }^{30}$ were cases of persons injured while on sidewalks. In both Carson $v$. Godley ${ }^{31}$ and Corven $v$. Sunderland, ${ }^{32}$ the landlord had concealed hidden defects, known to him, which is an entirely different question. In all the other cases cited by Mr. Justice Maxey (with the single exception of Folkman v. Lauer, ${ }^{33}$ which involves a different problem, and which will be discussed hereafter), the landlord was absolved from liability for one reason or another, and the statements relied upon are mere dicta, stating in general terms that a landlord is liable for a nuisance. ${ }^{34}$

25. Jackson v. Public Service Co., 86 N. H. 81, 86, I63 Atl. 504, 506 (1932). So also, in I TIFFANY, op. cit. supra note 19, at 68I, the author says:“. . . a nuisance is properly either an interference with a 'common right', such as that to use a highway, or an interference with the enjoyment of property." Likewise, he defines "strangers" as ". . . necessarily either the owners or occupants of nearby property, persons temporarily on such property, or persons on a neighboring highway or other public place." Id. at 674. To the same effect, see definition of strangers in I6 R. C. L. (I9I7) $\$ 593$, and discussion of nuisance in I6 id. \$ 594.

26. IO7 Pa. 85 (I884).

27. $108 \mathrm{~Pa} .489$ ( 1885 ).

28. I34 Pa. 334, I9 At1. 749 (I890).

29. 207 Pa. 43I, 56 Atl. 947 (rg04).

30. $230 \mathrm{~Pa} .25 \mathrm{I}, 79$ Atl. 552 (I9II).

3I. $26 \mathrm{~Pa}$. III (I856).

32. I45 Mass. 363 , I4 N. E. II7 (I887).

33. $244 \mathrm{~Pa}$. 605, 9I Atl. 218 (IgI4). In distinguishing this type of case, and after referring to it, the same court has said: "Where the public have the right or are invited generally to use the premises, the owner must have this in contemplation and his liability will be measured by such use. The effect of these cases is not to establish the rule that a landlord is liable for all defects which may cause injury to those who may enter the premises as visitors or occasional invitees." Mitchell v. George A. Sinn, Inc., 308 Pa. I, 5, I6r Atl. 538, 539 (I932).

34. Although the dissenting opinion cites it, the majority opinion does not refer to Moore v. Logan Iron \& Steel Co., 3 Sad. I43, 7 Atl. I98 ( $\mathrm{Pa}$. I886). There the landlord leased a dwelling. Subsequently, at the tenant's request, the landlord dug a hole, six feet deep, at the rear end of the lot. The hole promptly filled with water, and was left uncovered. Four weeks later, a niece (age $2^{T / 2}$ years) of one of the lessees, who visited the premises, fell in, and drowned. Following a verdict for the plaintiff, the lower court, in an opinion by Bucher, $P$. J., entered judgment for the defendant, upon the ground that the landlord owed no duty 
In fact, the only decision in England or America which supports the conclusion of the majority of the court in Deutsch v. Max, is Bailey $v$. $K e l l y .{ }^{35}$ In that case the landlord leased premises containing a cistern, twenty feet deep and eight feet in diameter, over which there was a defective cover. During the term of the lease, a domestic servant of the tenant was killed by falling into the cistern when the cover tilted. The trial court sustained a demurrer to the evidence. The Supreme Court, in an opinion by Justice Porter, held that the plaintiff was entitled to recover, upon the same principle advanced by Mr. Justice Maxey, namely, that the dangerous condition existing on the premises at the time the tenant took possession constituted a dangerous nuisance. Upon the second trial of the case there was a verdict for the plaintiff. The case came before the appellate court again, ${ }^{36}$ whereupon, by a four-to-three decision, in which Justice Porter, who had written the first opinion, concurred, the court reversed the position which it had taken on the first appeal, held that the nuisance theory was inapplicable to the facts, and ordered judgment entered for the defendant. The opinion of the majority was written by Mr. Justice Burch, who is now Chief Justice of Kansas. In discussing the case, Mr. Justice Burch said:

"A majority of the members of the court are convinced that the former decision was wrong. That the former decision was substantially unsupported by authority and was rendered against the settled law of this country is clear.

The court was conscious of the fact that it was extending the liability of the landlord as that liability had been previously understood, but believed the extension to be justifiable. . . When the landlord takes rent for premises containing a public nuisance he is liable. In this case the landlord took rent for the use of premises containing a pitfall which a portion of the public selected by the tenant was obligated to encounter. Consequently the court applied the nuisance theory and held the defendant liable.

to the tenant's guests. The Supreme Court affirmed upon the opinion of the court below. There the landlord, by his own active conduct, created the dangerous condition, while in Deutsch v. Max the landlord merely failed to repair the defects of time. In the Moore case, the court rejected the nuisance argument, upon the authority of the statement of Chief Justice Gibson, in Knight v. Abert, 6 Pa. 472 (1847), that "A man must use his property so as not to incommode his neighbour; but the maxim extends only to neighbours who do not interfere with it or enter upon it." (Italics mine.) In Deutsch v. Max, the nuisance theory could have been properly advanced if the defective balustrade in fact constituted a condition unreasonably dangerous to passersby on the sidewalk below, and such a person, injured by the fall thereof, had been the plaintiff. This factor, however, does not lend soundness to the decision on the record presented. A breach of a duty owed to one class of persons cannot create a cause of action in favor of a person not within the class. A plaintiff must show that as to him a duty was breached. Whitmore v. Orono Pulp \& Paper Co., 91 Me. 297, 39 At1. I032 (1808); Palsgraf v. Long Island R. R., 248 N. Y. 339, 162 N. E. 99 (I928); Venzel v. Valley Camp Coal Co., 304 Pa. 583, I56 Atl. 240 (I93I); Restatenent, ToRts (I934) $\$ 28 \mathrm{I}$, comment $c$.

35. 86 Kan. 9II, I22 Pac. I027 (1912).

36. Bailey v. Kelly, 93 Kan. 723, I45 Pac. 556 (I9I5). 
The difficulty with this decision is that it is not closely discriminative with respect to facts, ignores ideas of legal duty which experience has demonstrated to be well founded and fair, and involves the law in confusion concerning some of its fundamental principles." 37

From that day to this, no appellate court has followed the first decision in Bailey $v$. Kelly on its facts, until Mr. Justice Maxey, without referring to it, adopted the same reasoning and reached the same conclusion.

However, during the past sixty years there has been the development in some jurisdictions of one exception to the landlord's freedom from liability for conditions existing upon the premises at the time the tenant takes possession which are dangerous only to people coming upon the premises. In a few states, where land is leased for a so-called public or semipublic use, the landlord is under a duty to the lessee's patrons to take reasonable care to see that the premises are fit for the specific use for which they have been leased. Although the cases are not in complete accord, this exception has been accepted by the American Law Institute. The Restatement of the Law of Torts provides: "\$ 359. Where Land Leased for Purpose Involving Admission
of Numerous Persons.

A lessor who leases land for a purpose which involves the admission of a large number of persons as patrons of his lessee, is subject to liability for bodily harm caused to them by an artificial condition existing when the lessee took possession, if the lessor

(a) knew or should have known of the condition and realized or should have realized the unreasonable risk to them involved therein, and

(b) had reason to expect that the lessee would admit his patrons before the land was put in reasonably safe condition for their reception."

The comment to this section of the Restatement points out that liability is limited to the lessee's patrons who are admitted for the particular purpose of using the land for the particular purpose for which it was leased, and that the liability does not extend to other business visitors or to social insitors. Even as thus limited, however, this exception definitely clashes with traditional theories of non-liability and with the reasons therefor as above stated. Here is a type of case in which the rights of the patron do rise higher than those of the tenant, and in which the landlord may be subject to liability to such patrons even though he has made that full disclosure of existing defects to the tenant which would be sufficient to bar any action by the latter for personal injuries to him. 
The earliest case which forms the basis of this exception is Swords $v$. Edgar. ${ }^{38}$ The defendant, as owner, leased half of Pier II, New York City, under a five-year lease. At the time the tenant took possession the flooring was apparently sound, but in fact some of the pier supports were rotten, as the landlord actually knew. The tenant covenanted to keep the pier in repair, but there is no evidence that he had knowledge of the defective pier supports. Subsequently the pier collapsed, killing a longshoreman who was working on it. By a decision of four to three, the landlord was held liable. The court made the point that "though private property, it was held as such for public objects. There is an implied license to vessels upon navigable waters, to enter and occupy piers built into . . . such waters. . . . The keeping of such a pier is likened to the keeping of an inn"; ${ }^{39}$ furthermore, the defendant "leased it . . . in contemplation of the use to which it was to be put, indeed, so that such use might be made of it. As to the defendants, then, the plaintiff's intestate was lawfully upon the pier, and as to them, it was to him as if a public place or highway, upon which he had a right to go." 40 The court also said, "Moreover there was testimony tending to show an original faulty mode of construction", 41 and went on to hold definitely that the pier constituted a nuisance. Subsequently, in Edwards v. New York \& Harlem R. R., ${ }^{42} \mathrm{Judge}$ Earl, in referring to Swords v. Edgar, said: ". . . the ground of nuisance is the only one upon which that decision can stand. . . . A dock is regarded as a species of public highway, and the owner who suffers a nuisance to be created and continued upon his dock remains liable upon the ground of nuisance." 43

In the Edwards case, also decided by a court divided four to three, the defendant rented "Gilmore's Gardens" for a term of ten days for a $\$ 5,000$ rental. The premises were rented for "a pedestrian exhibition." While the tenant was in possession, a gallery, crowded with boisterous, stamping people, collapsed, injuring a patron standing beneath it. The majority of the court decided the landlord was not liable because of lack of evidence that he had actual knowledge the gallery was defective for the purposes for which it was leased. In view of the fact that this decision largely became the basis of the subsequent decisions imposing liability, it is interesting to note that Judge Earl specifically said:

38. 59 N. Y. 28 ( 1874$)$.

39. Id. at 3 I.

40. Id. at 32 . (Italics mine.)

4I. Id. at 36 .

42. $98 \mathrm{~N}$. Y. 245 ( 1885 ).

43. Id. at 255. (Italics mine.) In Campbell v. Portland Sugar Co., 62 Me. 552 (1873), decided a year earlier than Swords v. Edgar, also involving a defective wharf, the court likened the wharf to a public highway, expressly saying that it was "a place of public travel." $I d$. at $56 \mathrm{r}$. The case is not in point, however, on the general problem, because the landlord had covenanted to make all repairs, and was in fact in charge of the entire wharf at the time the plaintiff was injured upon it. 
"But where the landlord has created no nuisance, and is guilty of no willful wrong or fraud or culpable negligence, no case can be found imposing any liability upon him for any injury suffered by any person occupying or going upon the premises during the term of the demise; and there is no distinction stated in any authority between cases of a demise of dwelling-houses and of buildings to be used for public purposes. The responsibility of the landlord is the same in all cases." 44

The next case is Albert $v$. State. ${ }^{45}$ The defendant owned a summer amusement park. On it was a wharf, which constituted the only means of ingress to and egress from the park. At the time the tenant took possession, the wharf was in a dangerously defective condition, and subsequently collapsed, with resultant death to a patron. The court held the landlord liable, and denounced the wharf as "a nuisance of the worst character", making the landlord's liability turn upon whether he "knew or by the exercise of reasonable diligence could have known of its condition." 46 After referring to Swords v. Edgar, the court said, "But in any event, we think the case of Owings $v$. Jones, $9 M d$., ro8, a controlling authority." ${ }_{47}$ In Owings $v$. Jones, ${ }^{48}$ the plaintiff fell into a vault under the pavement on a public highway, and the court there quite properly placed liability upon a true nuisance theory. Subsequently, in Smith $v$. Walsh, ${ }^{49}$ in which a child of a sublessee of a portion of the premises, was killed by falling when a defective balustrade on a second floor porch gave way, the court held the landlord not liable, saying,

"Albert's case and others of that kind are wholly different from this. Of course the law will not permit an owner to rent property of a public character where people in large numbers are likely to gather, if he knows or ought to know it is unsafe, and then shelter himself behind a lease. There are a number of cases in which the owners had leased wharves, public halls, piers, or other property of a public nature and were held liable. Some of them, including Albert's case, are cited in those we have referred to. The public are deemed to be invited in such cases by the owners and they cannot receive rent for such uses and permit their tenants to bring, in large numbers, upon their property those who do not have the opportunity to inspect the property, unless they have exercised due care to see that it is safe. Such a place in bad condition is indeed 'a nuisance of the worst character.' So with defects and dangerous places in and about public highways where the public have the right to be. But such cases can have no controlling effect in one such as we have before us, and for the reasons we have given the appellant is not liable." 50

44. $98 \mathrm{~N}$. Y. at 249 . Italics mine.

45. $66 \mathrm{Md} .325,7$ Atl. 697 ( 1887 ).

46. Id. at 339,7 Atl. at 697 .

47. Id. at 338, 7 Atl. at 697 .

48. $9 \mathrm{Md}$. $\operatorname{10}$ ( $(1856)$.

49. 92 Md. 5 I8, 48 Ati. 92 (IgOI).

50. Id. at 533, 48 Atl. at 94 . 
In the same year in which Albert $v$. State was decided, another wharf case arose in Rhode Island, in Joyce $v$. Martin. ${ }^{51}$ The court overruled a demurrer to a declaration which alleged that the defendant was the owner of a pleasure resort, or park, which he leased for a term of eight years; that a part of this park consisted of a wharf extending into the river; that at the time of the leasing there was an opening in the wharf, which closed when boats pressed against the wharf, and that five years after the tenant took possession, no repairs having ever been made, the foot of the plaintiff, a patron, was crushed in this opening in the wharf. The court relied upon both Swords v. Edgar and Albert v. State.

The first case involving premises other than a public wharf in which liability was imposed, arose in Massachusetts in Oxford $v$. Leathe. ${ }^{52}$ The owner of a building entered into a written agreement whereby he "leased" an amusement hall for four nights to one Gleason; the box office receipts were to be under the owner's control until $\$ 20$ was paid him each night. The tenant's understood purpose was to give exhibitions of horse training. The plaintiff had ascended a flight of stairs to a platform, and was waiting upon it in front of the entrance for the doors to open, when it fell. In holding the owner liable, Justice Holmes said:

"It is not necessary to consider whether the agreement was a lease or a license, although we regard it as a license. . . . If the jury found that the use actually made of the platform was something which the defendant was bound to have contemplated, he was liable for any neglect of proper precautions to make it safe, whether Gleason also was to blame or not, just as in the case of premises let with a nuisance upon them. . . . We do not intend at all to enlarge the liability of landlords in cases where heretofore it has been decided that only the occupants of the land were responsible. . . . The object of the contract with Gleason was that the public should be invited, since it was from the public that the defendant was to get his pay. At the same time, the short and interrupted character of the occupation allowed to Gleason made it obvious that the safety of the building must be left mainly to the defendant." 53

5I. I5 R. I. 558, 1o At1. 620 (1887).

52. 165 Mass. 254,43 N. E. 92 (1896).

53. Id. at 255,43 N. E. at 93 . The limitation upon this case appears in Jordan v. Sullivan, I8I Mass. 348, 63 N. E. 909 (I902), in which the landlord leased a hall temporarily for the installation of a lodge. A curtain across the head of the stairs was pulled, darkening the stairway, and a guest fell in the dark and was injured. In affirming a directed verdict for the defendant, Justice Loring said: "The plaintiff is not helped by Oxford $v$. Leathe. . . . In that case the landlord was held liable for a defect which was on the premises when they were let, on the ground on which a landlord is liable for a nuisance which is on the premises when a lease is made, namely, on the ground that he has been paid for the very use of the property which has been made of it, and, having been paid for that, he is liable if it was defective when put to that use. - . But . - a landlord is under no greater liability to the guests of a tenant than he is to a tenant. And there is nothing here to show' that the landlord contemplated the use of the hall by guests within the meaning of that word in cases like Oxford v. Leathe." I8I Mass. at 350, 63 N. E. at 910. 
In the same year in which Oxford $v$. Leathe came down, the first of the so-called Willcox cases was decided in Tennessee. A landlord leased a property for a boarding house. At the time the tenant took possession, the supports for a rear porch, twelve feet high, were defective, as the landlord actually knew. After the tenant took possession some repairs were made by the landlord's carpenter, who then assured the tenant, "The porch is all safe now." 54 The porch collapsed, none the less, injuring the tenant, her daughter, and a boarder. In a variety of suits, all of them were permitted to recover. ${ }^{55}$ In Stenberg $v$. Willcox, ${ }^{56}$ which is the boarder's case, the court said that the plaintiff's recovery must be based upon the ground that the "landlord leased premises in a dangerous and unsafe condition, when he knew, or might, by the exercise of reasonable diligence and care, have known, of such unsafe condition, and upon the further ground that the plaintiff did not know of such unsafe condition, and could not have known of it by the exercise of reasonable diligence and care . . ." 57 On the petition for re-hearing, the court said that "the house was let to be used as a boarding house, and recommended by the landlord for that purpose. It was unsafe for that purpose, which is a quasi public purpose. . . . 58 Quite apart from distinguishing features in the facts of these Tennessee cases, the Supreme Court of Tennessee subsequently definitely limited their application to cases in which the landlord did not disclose to the tenant existing dangerous conditions. In Boyd v. McCarty, ${ }^{59}$ the court, referring to the Willcox cases, said that they "are obviously not relevant. These cases relate to defects of which the tenants are ignorant." ${ }^{0}$ Also, in Smith $v$. Tucker, ${ }^{61}$ the court considered the Willcox cases as cases involving the principle that where a landlord holds out that repairs which he has actually made have rendered a dangerous condition safe, whereas in fact he has not, he is liable for actively leading the tenant, or others, into a trap. This well recognized principle is separately stated in Section 362 of the Restatement of the Law of Torts.

In the year following the first of the Willcox cases, Fox v. Buffalo Park $^{62}$ was decided. The owner of a race track and grandstand leased it to

54. See Willcox v. Lillie Hines, roo Tenn. 524, 531, 45 S. W. 78r, 782 (1898).

55. Hines v. Willcox, 96 Tenn. I48, 33 S. W. 914 (1896) (tenant's suit); Stenberg v. Willcox, 96 Tenn. 163, 33 S. W. 917 (1896) (boarder's suit); Hines v. Willcox, Stenberg v. Willcox, 96 Tenn. 328, 34 S. W. 420 (I896) (petitions for rehearing denied in suits of tenant and boarder) ; Willcox v. Lillie Hines, I00 Tenn. 524, 45 S. W. 78I (I898) (daughter's suit); Willcox v. Lucy S. Hines, I00 Tenn. 538, 46 S. W. 297 (1898) (tenant's suit).

56. 96 Tenn. 163,33 S. W. 917 (I896).

57. Id. at $164,33 \mathrm{~S}$. W. at $9 \mathrm{I7}$.

58. Hines v. Willcox, 96 Tenn. $328,332,34$ S. W. 420,421 (I896).

59. 142 Tenn. 670, 222 S. W. 528 (1920).

6o. Id. at $677,222 \mathrm{~S}$. W. at 530 .

6r. I5I Tenn. 347,270 S. W. 66 (I925). $1120($ I 900$)$. 
a cycling club for a term of one day. Due to the faulty original construction of the stand, which the owner had erected three years previously, it collapsed, injuring a patron. The charge of the trial court made the defendant's liability turn solely upon whether or not the original construction was faulty. No question of disrepair was involved. There was a verdict for the plaintiff, and the judgment entered thereon was affirmed. Judge Ward said: "The inference from the verdict is that the jury found that the structure was created unsafe and dangerous by the defendant itself." ${ }^{63}$ He then went on to say: ". . . the lessors or owners of the buildings or structures ['in which public exhibitions and entertainments are designed to be given and for admissions to which the lessors directly or indirectly receive compensation'] hold out to the public that the structures are reasonably safe for the purposes for which they are let or used and impliedly undertake that due care has been exercised in the erection of the buildings." 64 Judge Green, concurring, said:

"It should be remarked that the defendant had surrendered possession of the premises to the 'lessee' for but a single day. It still owed a continuing duty to the public and was not relieved from its performance by letting the structure to another for so short a period of time." 65

This decision was followed in New York by Barrett $v$. Lake Ontario Beach Improvement $C o .{ }^{66}$ which also involves a case of original faulty construction as distinct from disrepair by the passage of time. The defendant owned a bathing establishment, containing a toboggan slide running down to the water. The platform of the slide was twenty-five feet above the ground, and the railing around it left ample space for a person who slipped upon the wet surface of the platform to slide out and fall to the ground, as the plaintiff did. The defendant had leased the premises for the season, the lease providing that the lessee could make no alterations in the premises without the written consent of the lessor. In holding that the landlord was liable to the patron, Judge Gray said that "the essential principle of the doctrine is the omission, or the neglect, of a duty in preparing a structure, to be put to a particular public use, to make it reasonably fit, or safe, for that use." 67

This was followed in New York by Junkerman $v$. Tilyou Realty Co. ${ }^{68}$ The defendant leased an amusement park for a term of fifteen years, and almost immediately sub-let it for a term of ten years, after which the sublessee assigned the lease to the Jankelson Company. A few months later,

63. 2I App. Div. at 327, 47 N. Y. Supp. at 792.

64. Ibid.

65. Id. at $334,47 \mathrm{~N}$. Y. Supp. at 796.

66. I74 N. Y. 310, 66 N. E. 968 (I903).

67. Id. at $315,66 \mathrm{~N}$. E. at 970 .

68. 213 N. Y. 404 , I08 N. E. I90 (I9I5). 
while a baby parade was being held on a boardwalk in the park, a portion of it collapsed, and the plaintiff, who was a spectator, and apparently a patron of the park, was injured. At the time the original lessee sub-leased, he knew the walk was in a dangerous condition. In an opinion by then Judge Cardozo, the original lessee, who was not in possession, was held liable. Judge Cardozo said:

"We may say more simply, and perhaps more wisely, rejecting the fiction of invitation [by the defendant to the patron], that the nature of the use itself creates the duty, and that an owner is just as much bound to repair a structure that endangers travelers on a walk in an amusement park as he is to repair a structure that endangers travelers on a highway. Whatever the underlying principle that explains the rule, the rule itself is settled. The owner of such a park must use all reasonable care to make its structures safe before he leases it for his profit." 69

Subsequently, in Warner $v$. Lucey, ${ }^{70}$ the rule was extended to impose liability upon a landlord of a garage building. The lease was for a term of one year, and at the time the tenant took possession the landlord knew that the freight elevator had a maximum capacity of only 4000 pounds, and that many automobiles were of a greater weight. The elevator broke as an automobile was being lowered upon it, injuring a friend of the automobile owner. Judge Van Kirk said:

"The garage was intended by the lessors and tenants for public patronage, - . . It was a public use or place, as is an inn or warehouse. From this use both parties derived a profit; the lessors through the rent reserved." 71

The court cited and applied the rule laid down in the Barrett case.

On the other hand, in Campbell v. Elsie Holding Co. ${ }^{72}$ the limitation of the landlord's liability is seen. The landlord leased a building for a warehouse. Owing to the nature of the construction of the building, at the eighth floor level there was an eighteen inch open space between the edge of a freight elevator and the hall. The elevator was opened and unguarded, and an employee of the lessee fell through this opening while unloading a truck on to the elevator, and was killed. In denying liability, the court drew a sharp line between the leasing of premises for a public use $\left(i . e_{\text {., for }}\right.$ a use which contemplated the going upon the land of members of the public generally) and a private use, saying,

69. Id. at $409,108 \mathrm{~N}$. E. at I9I.

70. 207 App. Div. 24I, 201 N. Y. Supp. 658 (3d Dep't I923), aff'd, 238 N. Y. 638, I44 N. E. 924 (rg24).

7r. 207 App. Div. at $243,244,201$ N. Y. Supp. at 660.

72. 25 I N. Y. 446 , I67 N. E. 582 (I929). 
"It is a familiar rule that the lessor of a building is not liable for injuries to the lessee, or others upon the premises in the right of the lessee, resulting from a structural defect existing when the lessee took possession. . . . The rule does not apply if the lessor rents the premises for a public use to which he knows they are unsuited." 73

So also, in Lafredo v. Bush Terminal Co., ${ }^{74}$ the landlord was held not liable to a workman who was injured when a defective beam in a pier gave way. The court said:

"This part of the pier was private, and it was not let for the purpose of being used as a public place. It was, on the contrary, demised for the 'exclusive use' of the lessee and the general public was excluded." $7 \overline{5}$

In this case, the pier was a quarter of a mile in length, and in the course of time undoubtedly a substantial number of people would go upon it.

In view of these latest decisions of the Court of Appeals, there appears to be no tendency in New York to extend the public use cases beyond situations where it is contemplated that the public in general will freely come and go upon the premises. Whether or not the public use rule applies to premises which are leased to be used as a shop or a general store, remains an open question, although the decision in Warner $v$. Lucey points toward liability in such a case.

While the New York law was formulating, a number of cases arose in other jurisdictions. In Eckman v. Atlantic Lodge ${ }^{76}$ Chief Justice Gummere approved the principle of Fox v. Buffalo Park in a dictum. The defendant, however, was the lessee in possession. In Kane $v$. Lauer, $^{77}$ the defendant leased a baseball park and grandstand thereon for a term of two years. At the time some of the uprights supporting the stand were decayed. The stand collapsed during the term of the lease, injuring a patron of the lessee. The landlord was held liable, upon the theory that he was maintaining a nuisance, and that "as the tenants were required by the lease to use the property for the entertainment of the public the landlord participated in inviting the spectators to witness the games and it was his duty to exercise reasonable care to the end that those who occupied his buildings should not be subjected to peril from a condition existing at the time the tenants were put in possession." 78 In Folkman v. Lauer, ${ }^{79}$ which arose out of the same accident, the Supreme Court adopted and followed the opinion of the Superior Court in the prior case.

73. Id. at $448,167 \mathrm{~N}$. E. at 582 .

74. 26I N. Y. 323,185 N. E. 398 (1933).

75. $I d$. at $327,185 \mathrm{~N}$. E. at 399.

76. 68 N. J. L. IO, II, 52 Atl. 293, 294 (I902).

77. $52 \mathrm{~Pa}$. Super. 467 (I9I3).

78. Id. at 472.

79. 244 Pa. 605, 9 I At1. 218 (IgI4). 
In Colorado, the court held in Colorado Mortgage \& Investment Co. v. Giacomini, ${ }^{80}$ that the principle imposing liability upon a landlord should be applied to the leasing of a hotel. The defect there was in a passenger elevator. The court said that the landlord was liable for existing defects "where the property is leased for public or semi-public purposes." It went on to hold that a hotel in the main business district of Denver, which contained a hundred sleeping rooms, is "a semi-public place". Recently the same court has greatly extended the meaning of a semi-public use by holding in Gilligan v. Blakesley ${ }^{81}$ that it included a doctor's office in a large office building. The doctor tenant was in sole possession of the portion of the premises involved. A back door opened on to an unguarded drop of twelve feet. A patient of the doctor opened this door and fell, receiving serious injuries. The court sustained a recovery against the landlord. ${ }^{82}$

In Utah and in Oklahoma the rule imposing liability was followed in cases involving amusement parks. In the Utah case ${ }^{83}$ a shooting gallery was in such defective condition that bullets glanced out to where patrons were passing along a near-by path; while the Oklahoma case ${ }^{84}$ involves the collapse of a portion of a grandstand. The Utah court discussed liability along the lines of nuisance; while the Oklahoma court considered the case upon the theory that the landlord was extending an invitation to the public to attend the premises, and that its duty to the public remained the same whether it personally received the admission fees or donated the same to someone else.

In 1932 the public use rule was extended in both Kansas and Oregon to include premises which had been leased to be used as a grocery store. But during the same year, the Supreme Court of New Hampshire took a step in the opposite direction, although the question did not squarely arise on the facts before the court. In Turner $v$. Kent, ${ }^{85}$ the landlord leased a store, to be used as a grocery and meat store. There was a hole six inches deep and seven inches in diameter in the pavement floor within the premises, as the landlord knew. A customer of the tenant stepped into this and was injured. In holding that the landlord was liable, Mr. Justice Hutchison said: ". . . the injured party here was a customer of the store, a part of the general public invited to this place of business, whereas in the Bailey

8o. 55 Colo. 540, I36 Pac. ro39 (I9r3). An intermediate appellate court had earlier held in Copley v. Balle, 9 Kan. App. 465, 60 Pac. 656 (1900), that the public use principle was applicable to a lessor of a hotel property on which there existed an excavation into which a hotel guest fell.

81. 93 Colo. 370, 26 P. (2d) 808 (I933).

82. Squarely contrary is McCain v. Majestic Bldg. Co., r20 La. 306, 45 So. 258 (rgo8), in which a theatre patron walked through a door marked "Exit", fell some distance, and died. In denying the landlord's liability, the court pointed out that the danger would have been eliminated by locking the door, and that the duty to do so was upon the tenant.

83. Larson v. Calder's Park Co., 54 Utah 324, I80 Pac. 599 (I9I9).

84. Tulsa Entertainment Co. v. Greenlees, 85 Okla. II8, 205 Pac. I79 (I922).

85. I34 Kan. 574, 7 P. (2d) 513 (1932). 
case the injured one was an employee of the tenant, who stood in the same relation to the owner as did the tenant and no higher, as does a guest or any of the invited public." 86 The court based liability upon the principle that the landlord leased the premises for a public use, for which he knew they were unfit, and that the premises, under such circumstances, constituted a nuisance. In Senner $v$. Danewolf, ${ }^{87}$ the premises were leased to be used by the tenant as a grocery store and living quarters. Within the premises and along the side was a walk, and adjacent thereto was an unguarded opening, leading down steps to a cellar door. At night, a customer of the tenant who had come out of the side door after making a purchase, fell into the opening. The court imposed liability upon the landlord, on the theory that he was the creator of a dangerous condition, and that the unguarded opening, although it was well within the premises, constituted a nuisance. The authorities relied upon by the court are the first appeal of Bailey $v$. Kelly, ${ }^{88}$ which, as has already been pointed out, was overruled on the second appeal, and Larson v. Calder's Park Co. ${ }^{89}$ The court then goes on to quote from Edwards v. New York \& Harlem $R$. R.,90 but by omissions twists the meaning of the language quoted to the exact opposite of what the New York court in fact said. According to the quotation, as given by the Oregon court, the landlord is equally liable for existing dangers in cases of the demise of dwelling houses and of buildings to be used for public purposes. What Judge Earl actually said was that the landlord was equally free of liability in both cases.

As opposed to these decisions in Kansas and Oregon, the Supreme Court of Missouri squarely held in Bender $v$. Weber ${ }^{91}$ that a lease of premises for a grocery store did not come within the public use exception to the landlord's non-liability. And in Clark v. Chase Hotel Co., ${ }^{92}$ the St. Louis Court of Appeals held that the lease of a turkish bath was not a lease for a public purpose merely because it was leased for a commercial purpose.

The recent New Hampshire decision of Jackson v. Public Service Co., ${ }^{93}$ although distinguishable upon its facts in that the defect arose after the leasing, states the landlord's non-liability in broad language. The defendant leased a park, in which was a skating rink. This is undoubtedly a lease for a public use, under all of the other decisions. The plaintiff, a patron of the lessee, was leaning against the window sill watching people skating, when a shutter fell, injuring him. Chief Justice Peaslee considered

86. $I d$. at 576,7 P. (2d) at 5I4. Italics mine.

87. 139 Ore. 93,6 P. (2d) 240 (I932).

88. 86 Kan. 9II, I22 Pac. I027 (I9I2), cited supra note 35 .

89. 54 Utah 324, I80 Pac. 599 (I9I9), cited supra note 83.

90. 98 N. Y. 245 ( 1885 ), cited supra note 42.

9I. 250 Mo. 55I, I57 S. W. 570 (I913).

92. 74 S. W. (2d) 498 (Mo. App. I934).

93. 86 N. H. 8r, I63 Atl. 504 (I932). 
the question upon the general principle of a landlord's non-liability. . Without referring to the question of a public use, he said:

"Another conclusive answer to the claim advanced is that the doctrine of liability for nuisance upon the premises does not apply as: between a landlord and his tenant, or those claiming under the tenant. That doctrine depends upon a theory of unreasonable invasion of one's rights in premises by acts done upon or outside thereof. . . . It cannot be relied upon by the tenant or his invitees as a ground for recovery from the landlord because of defects in the leased premises. . . So long as there was no invasion of the premises by the landlord there was no liability for their condition, in the absence of warranty or deceit." $0 *$

The foregoing cases do establish that a definite change is taking place in the American law pertaining to a landlord's liability for disrepair, and that the Restatement accurately states the decided cases and the present tendency. In these cases involving the lessee's patrons, a substantial number of widely scattered jurisdictions have agreed on an extension of liability which cannot be reconciled with traditional theories supporting the general rule of non-liability, and which gives to this particular type of tenant's invitee a greater right against the landlord than that possessed by the tenant himself.

The real problem today is to determine the underlying reasons for this changed attitude, in an attempt to determine how far the liability will be carried in later cases. The opinions of the courts do not solve the problem. They were written after the decisions had been made, and in order to confer respectability upon them. Many of the opinions call the condition a nuisance, as Mr. Justice Maxey did in Deutsch v. Max. Except for cases involving defects in a public wharf which constituted, for all practical purposes, an extension or continuation of a true public highway, ${ }^{95}$ the nuisance theory is not sound. This is a typical example of what Professor Bohlen has picturesquely called the use of "the 'invocatory' word." 96

The cases which have arisen have generally involved serious injuries or death. Also, in Oxford $v$. Leathe, the "lease" was for only four nights; while in the leading case of Fox v. Buffalo Park, it was for a single day.

94. Id. at 86,163 Atl. at 506, 507. The only public use case absolving a landlord from liability, in which the defect did exist at the time the tenant took possession, is Dwyer v. Robinson, xIo Fed. 99 (C. C. S. D. Ohio I899), whichu held that the landlord of an opera house was not liable to a patron of the tenant who was injured by the fall of the ceiling due to a defective truss, which was rotten at the time the lessee took possession.

95. Cf. Restatement, Torts (1934) § $36 \%$.

96. Old Phrases and New Facts (1935) 83 U. of PA. L. Rev. 305, 3xo. He goes on to say : "By this is meant a word which has customarily been used to describe a situation that has habitually been recognized as requiring a particular legal result. Students are being taught to realize that, where this result is desired, courts often justify it by using such a word to describe a situation to which the word is entirely inappropriate if it be taken in its traditional sense and not so extended as to be valueless as a word of definition or even of description." Ibid. 
These were two of the earlier cases, and it is obvious that under such circumstances the "tenant" would have neither the opportunity nor inclination to make repairs or even ascertain their need. Certainly his patrons would not be alert to discover danger. Further, there is little likelihood of the ability of such transitory "tenants" to satisfy judgments against them. In addition, in the Fox case and in several others, the defect was not one of disrepair due to the wear and tear of time, but an original faulty construction, in which situation there is the analogy of a dangerous trap actively created by the landlord. In the Barrett case, there was the additional feature that the lease forbade alterations by the tenant which would have remedied the structural defect. Such factual situations were the breeding grounds of this new species of landlord's liability. Some care and no great expense by the landlord would have prevented the damage. As a practical matter, the landlord could readily foresee that if he did not take steps to make the premises safe, nobody else would, and that a grave risk of serious injury to a substantial and determinable group of people would result. In addition, the vestigial remnants of feudal immunities carry little weight in the tort law of twentieth century America. In juristic as well as popular thinking, so-called "human rights" have been stressed to the subordination of "property rights." Thus, in those public use cases which arose, the equities were strongly with the injured and innocent patron, and the courts' intuitive judgment called for the imposition of a liability difficult to rationalize with existing legal concepts. The problem is not one of logic nor one of merely following precedents. It is a question of social expediency.

The problem today is to determine whether the general rule which relieves the landlord from liability for existing defects is out of line with present-day conditions and social needs, and whether the so-called public use exception should be extended so as to absorb the original rule, and thus effect a complete substantive change in this branch of tort law. If such a change is to be made, Deutsch $v$. Max will stand as a pioneer case, irrespective of the unsoundness of the reasoning contained in the majority opinion. In the last three years there has been a slight tendency in a few cases to extend the public use rule to situations which do in no true sense involve a real public use of the premises. To summarize, the cases dealt first with public wharves. ${ }^{97}$ These, in turn, were followed by a second group of cases, which extended the rule to include amusement parks and similar places, such as ball parks. ${ }^{98}$ Aside from these two classes of cases,

97. Albert v. State, 66 Md. 325, 7 At1. 697 (I887), cited note 45, supra; Swords v. Edgar, 59 N. Y. 28 ( 1874 ), cited note 38, supra; Joyce v. Martin, I5 R. I. 558, to Atl. 620 (1887), cited note $5 \mathrm{I}$, supra.

98. Oxford v. Leathe, I65 Mass. 254, 43 N. E. 92 ( 1896 ), cited note 52, supra; Junkerman v. Tilyou Realty Co., 213 N. Y. 404,108 N. E. I90 (I9I5), cited note 68, supra; Tulsa Entertainment Co. v. Greenlees, 85 Okla. II8, 205 Pac. I79 (I922), cited note 84, supra; Kane v. Lauer, $52 \mathrm{~Pa}$. Super. 467 (Igr3), cited note 77, supra; Folkman v. Lauer, $244 \mathrm{~Pa}$. 605, 9r Atl. 218 (I9I4), cited note 79, stipra; Larson v. Calder's Park Co., 54 Utah 324, I80 Pac. 599 (I9I9), cited note 83, supra. 
there are a few western cases, and one New York case, all of quite recent origin, which extend the principle further. The earliest was in 1896 , when the Supreme Court of Tennessee applied the public use doctrine to a boarding house. ${ }^{99}$. In 1900 an intermediate appellate court in Kansas extended the rule to a hotel property, ${ }^{100}$ as did the Supreme Court of Colorado in I9I3. ${ }^{101}$ In I923 the New York courts held that a public garage came within the exception. ${ }^{102}$ The greatest extension of the public use rule took place in I932, when the Supreme Courts of Kansas ${ }^{103}$ and Oregon ${ }^{104}$ applied the principle to a grocery store, and in I933, when the Colorado court applied it to a doctor's office. ${ }^{105}$ It should be noted that all of these decisions considered the problem from the standpoint of an exception to a general rule of non-liability. Certainly, however, in Colorado at least, the extension does not leave much of the so-called "general rule." But the trend has not been all one way, as witness the cases referred to in Missouri, ${ }^{100}$ Louisiana, ${ }^{107}$ the federal court ${ }^{108}$ and New Hampshire, ${ }^{109}$ and the limitations placed upon the exception in the most recent decisions of the New York Court of Appeals. 110

It can be argued that the question of extending a landlord's liability to other classes of the tenant's licensees than his patrons, and to include all types of premises, including private dwellings, is merely one of degree. The landlord can frequently foresee that the type of tenant who will rent a rundown house will have neither the inclination nor the financial means to spend money on repairs. Frequently, also, there is a real chance, at least, that the tenant will not warn his servants, social guests, and other licensees, of existing dangers. There is a greater chance that he will not make even a lay inspection to discover unknown but ascertainable dangers. If foreseeability of a risk of injury is to be the sole test, the public use exception imposing liability will in time become the new general rule.

But the question of imposing liability upon a landlord is not purely one of whether he can foresee a risk of injury to the tenant's licensees.

99. Stenberg v. Willcox, 96 Tenn. 163,33 S. W. 917 (1896), cited note 56 , supra.

Ioo. Copley v. Balle, 9 Kan. App. 465,60 Pac. 656 (Ig00), cited note 80, supra.

Ior. Colorado Mortgage Investment Co. v. Giacomini, 55 Colo. 540, 136 Pac. 1039 (Igr3), cited note 8o, supra.

102. Warner v. Lucey, 207 App. Div. 241, 20I N. Y. Supp. 658 (3d Dep't 1923), aff'd, 238 N. Y. 638 , I44 N. E. 924 (1924), cited note 70, supra.

I03. Turner v. Kent, 134 Kan. 574, 7 P. (2d) 513 (1932), cited note 85, supra.

104. Senner v. Danewolf, I39 Ore. 93, 6 P. (2d) 240 (I932), cited note 87, supra.

I05. Gilligan v. Blakesley, 93 Colo. 370 , 26 P. (2d) 808 (I933), cited note 8I, supra.

I06. Bender v. Weber, 250 Mo. 55I, I57 S. W. 570 (I9r3), cited note 9I, supra; Clark v. Chase Hotel Co., 74 S. W. (2d) 498 (Mo. App. I934), cited note 92, supra.

I07. McCain v. Majestic Bldg. Co., 120 La. 306, 45 So. 528 (Ig08), cited note 82, supra.

I08. Dwyer v. Robinson, IIo Fed. 99 (C. C. S. D. Ohio I899), cited note 94, supra. supra.

rog. Jackson v. Public Service Co., 86 N. H. 8r, I63 Atl. 504 (1932), cited note 93,

IIo. Campbell v. Elsie Holding Co., 251 N. Y. 446, I67 N. E. 582 (r929), cited note 72, supra; Lafredo v. Bush Terminal Co., $26 \mathrm{r}$ N. Y. 323, I85 N. E. 398 (1933), cited note 74, sapro. 
There are many types of activity in present-day life which create some risk of injury but whose social utility is sufficient to prevent the imposition of a liability which would discourage them. In the opinion of the present writer, it is still socially desirable not to discourage investment in and ownership of real estate, particularly private dwellings. A large part of the community must continue to live in rented homes. The profits from real estate in recent years have not been large, and the burden of taxes and other charges has become increasingly heavy. Adding to those burdens will require a rental the tenant cannot afford to pay, or discourage investment in the houses the tenants need. ${ }^{111}$ In Pennsylvania a landlord will no longer dare to lease a private dwelling which to his knowledge contains any defect of potentially dangerous characteristics, no matter how willing the tenant may be to accept the property as is. The landlord must expend whatever amount is necessary to put the premises in a thoroughly safe condition.

A further risk to which the landlord is subjected under the doctrine of Deutsch v. Max is that of becoming answerable for defects which in fact did not exist at the time he delivered possession of the premises. An injury may occur some years after the tenant takes possession, and at some subsequent time the jury must determine the frequently difficult question of fact as to when the defect first came into being. With a landlord defendant and the injured plaintiff before them, the inclination of the jury would be to resolve any doubts in favor of the plaintiff and to find as a fact, even on dubious evidence, that the defect antedated the lease and was known to the landlord when he delivered possession.

It is submitted further that where the danger is a serious one and known to the tenant, he will frequently be possessed with sufficient humanity to give the necessary warning which will enable the licensee to avoid injury. This is so even conceding that the tenant may not be sufficiently versed in tort law to appreciate his own legal duty as possessor to his licensees. In those exceptional situations involving a foreseeably grave risk of serious injury, the courts will continue to find a form of words to impose a liability believed to be justified by the particular facts. The broad language of Deutsch v. Max is not necessary to deal with those exceptional situations, and the decision upon its facts is, in the opinion of the present writer, of questionable soundness.

III. It may also be pointed out that in recent years, particularly in the metropolitan districts, trustees of many small estates have been forced to become landlords by the necessity of taking title to property through mortgage foreclosure sales. Experience of many of these trustees has been that it is difficult to obtain sufficient income from the property to pay much more than taxes and insurance, let alone any adequate return on the original mortgage investment. This situation will probably correct itself with the passage of time and the improvement of business conditions, but for the present the decision in Deutsch v. Max lays an added burden of expense upon the beneficiaries of such trusts. 